\title{
Presence of Palaemon macrodactylus Rathbun 1902 (Crustacea: Decapoda: Caridea: Palaemonidae) in Mar del Plata harbor, Argentina: first record from southwestern Atlantic waters
}

\author{
Eduardo D. Spivak ${ }^{1, *}$, Enrique E. Boschi ${ }^{2}$ \& Sergio R. Martorelli ${ }^{3}$ \\ ${ }^{1}$ Departamento de Biología, Facultad de Ciencias Exactas y Naturales, Universidad de Mar del Plata, Casilla \\ de Correo 1245, 7600, Mar del Plata, Argentina; ${ }^{2}$ Instituto de Investigación y Desarrollo Pesquero, \\ Argentina; ${ }^{3}$ Centro de Estudios Parasitologicos y Vectores, La Plata, Argentina; *Author for correspondence \\ (e-mail:espivak@mdp.edu.ar)
}

Received 30 June 2004; accepted in revised form 10 February 2005

Key words: Argentina, Caridea, introduced species, Palaemon macrodactylus, Palaemonidae, prawn, shrimp

\begin{abstract}
Adults of the palaemonid prawn Palaemon macrodactylus Rathbun, 1902 were reported for the first time from the southwestern Atlantic waters. Males and ovigerous females were collected in Mar del Plata harbor $\left(38^{\circ} 03^{\prime} \mathrm{S} ; 57^{\circ} 31^{\prime} \mathrm{W}\right)$, Argentina; larvae obtained from one of the collected females were reared in the laboratory until the juvenile stage. The geographical range of $P$. macrodactylus was previously restricted to the Pacific Ocean: it was originally described in Japan and has been reported as an invasive species in the western coast of USA in the 1950's and in Australia in the 1970's. Recently, this prawn has been also reported from European waters.
\end{abstract}

\section{Introduction}

The migrant prawn, grass shrimp, or oriental shrimp, Palaemon macrodactylus was originally described from Japan (Rathbun 1902), and is widely distributed in Japan, Korea and northern China (Newman 1963). In the western Pacific, it was also mentioned as a possible invasive species of southern Australian waters (Buckworth 1979; Furlani 1996). P. macrodactylus was introduced in San Francisco Bay (USA), probably from Japan or Korea, in the early 1950's (Newman 1963; Jensen 1995). According to Jensen (1995), it "has become exceptionally abundant in San Francisco Bay and has progresively spread north and south, recently appearing in Wilapa Bay, Washington, and also in Malibu Lagoon and Long Beach Harbor, California". In fact, it was also found in Los Peñasquitos Lagoon, near San Diego, California (Williams et al. 1999). The introduction of this species in European coastal waters was very recently reported. It was found in the Guadalquivir estuary, southern Spain, in 1997 (Cuesta et al. 2004), in the Orwell estuary in Suffolk, eastern England in 2002 (Ashelby et al. 2004), in the harbor of Zeebruge in Belgium in July, 2004, and afterwards in a number of localities in Belgium and the Netherlands (d'Udekem d'Acoz et al. submitted), and in Germany in 2004 (González-Ortegón, Cuesta \& Schubart, personal communication).

Several aspects of $P$. macrodactylus biology have been studied: osmoregulatory capacities (Born 1968), larval development (Little 1969), the attachment of eggs to the pleopods and the formation of the egg outer investment coat (Fisher 
and Clark 1983), the association of eggs with aquatic bacteria (Fisher 1983a), the infection by the fungus Lagenidium callinectes Couch 1942 (Fisher, 1983b), and the energy budgets for larvae (Chin et al. 1992).

According to the U.S. National Marine Fisheries Service, the introduction of pathogenic organisms may be possible with the establishment of exotic species of shrimp, like $P$. macrodactylus (Anonymous, 1997). Stages of merogony of Aggregata spp., a coccidian parasite, have been reported in Palaemon adspersus Rathke 1837 and P. elegans Rathke 1837 (Gestal et al. 2002), and $P$. adspersus could be experimentally infected with the White Spot Syndrome Virus (WSSV) (Corbel et al. 2001).

In the present study, we document the presence of P. macrodactylus in Mar del Plata Harbor, Argentina. This is the first report of the species in the southwestern Atlantic Ocean.

\section{Study site, materials and methods}

Mar del Plata $\left(38^{\circ} 03^{\prime} \mathrm{S} ; 57^{\circ} 31^{\prime} \mathrm{W}\right)$ is the most important tourist resort in Argentina. Its harbor, limited by two breakwaters, is formed by two sectors. The south sector is commercial, the north sector is an Argentine Navy base; between them there are facilities for nautical sports (Club Náutico). The commercial port handles exports of 111,000 t grain and 68,500 t fish annually, in addition to domestic cargo, but its main activity is deep-sea and coastal fishing. Macrobenthic communities of Mar del Plata Harbor have been widely studied over more than 30 years (see Pezzani et al. 1996; Excoffon et al. 1999; Elías and Vallarino 2001 and references herein).

P. macrodactylus were collected with a hand net in the subtidal of Mar del Plata harbor. The first specimen found on 14 March 2000 was an ovigerous female, additional specimens were obtained subsequently in the same area. Approximately 300 larvae hatched from an ovigerous female collected on 11 March 2004, and 30 of them were reared in the laboratory in 35 PSU filtered sea water, $20^{\circ} \mathrm{C}$, and 14:10 (L:D) photoperiod. The larvae were fed with newly hatched Artemia sp. nauplii and examined daily for molting. Adults and larvae were fixed in $4 \%$ formalin.
Carapace length, from the tip of the rostrum to the postero-dorsal extreme, was measured with an micrometer eye-piece in all adults and in 10 zoea I.

Material examined: 1 ovigerous female, "Escollera Norte", Mar del Plata Harbor, Argentina, 14 March 2000, coll. Gregorio Bigatti; 1 ovigerous female, 3 females, and 10 males, "Club Náutico", Mar del Plata Harbor, Argentina, 10 December 2003, coll. S. Martorelli; 1 ovigerous female, "Club Náutico", Mar del Plata Harbor, Argentina, 7 March 2004, coll. Paola Silva.

A male, the parental female, and several larvae of P. macrodactylus from Mar del Plata harbor have been deposited at the Museo Argentino de Ciencias Naturales "Bernardino Rivadavia" (Buenos Aires, Argentina) with the accession numbers MACN-In 36242, 36243 and 36244, respectively.

\section{Results and discussion}

The adults of $P$. macrodactylus showed the diagnostic characters stated by Rathbun (1902), and Newman (1963). The carapace length ranged from 16.5 to $19 \mathrm{~mm}$ (ovigerous females), 11.8 to $14.1 \mathrm{~mm}$ (non-ovigerous females) and 9.7 to $13.5 \mathrm{~mm}$ (males). The larvae agreed with the descriptions of Little (1969). The carapace length of zoeas I was $1.10 \pm 0.03 \mathrm{~mm}(n=10)$. The number of zoeal stages ranged from 6 to 8 .

A recent survey of the knowledge about exotic marine organisms in coastal and shelf areas of Uruguay and Argentina revealed that there are 31 introduced and 46 cryptogenic species (Orensanz et al. 2002). Most of the introduced species (22) are sessile or sedentary (algae, Polychaeta, Bivalvia, Cirripedia, Bryozoa, Ascidiacea), the remaining species included Gastropoda (2), Amphipoda (1), Isopoda (5) and a crab. The latter, Pyromaia tuberculata (Lockington, 1877), was the only invasive decapod reported in this area; other reports of 'new' decapods along Argentine coast corresponded to natural fluctuations of the geographical range of 'northern' species such as Emerita brasiliensis Schmitt 1935, Callinectes sapidus Rathbun 1895, and Arenaeus cribarius (Lamarck 1818) (Orensanz et al. 2002). However, it should be noted that $P$. tuberculata, a western 
Pacific species, was first reported in Brazilian waters, so its introduction to the Argentine continental shelf may also be also the consequence of the expansion of the southern range of a 'northern' population (Schejter et al. 2002).

The decapod crustaceans of Argentine coastal waters have been carefully studied by Boschi (1964, 2000) and Boschi et al. (1992). P. macrodactylus had not been reported in this region until this study, and it is possible that this species may have been introduced in Mar del Plata harbor from the Pacific with discharged ballast water. Palaemon macrodactylus is considered an invasive species, since it has successfully colonized northeastern Pacific coasts and estuaries after an accidental introduction (Jensen 1995). The recent introduction of $P$. macrodactylus in European waters also occurred in harbors (e.g. Sevilla, Felixstowe), and possibly was due to the same mechanism proposed here (Ashelby et al. 2004; Cuesta et al. 2004).

The port of Mar del Plata is characterized by highly diverse fouling communities that include many of the introduced or cryptogenic species reported in Argentine waters (Orensanz et al. 2002: Tables 1 and 2). Since P. macrodactylus was not mentioned in recent papers dealing with the macrobenthic fauna of Mar del Plata harbor (e.g. Pezzani et al. 1996; Excoffon et al. 1999; Elías and Vallarino 2001), we suggest that its introduction is a recent event.

Among the species introduced in Argentine marine and estuarine waters, five have had a significant ecological impact: Balanus glandula (Darwin 1854), Limnoperma fortunei (Dunker 1857), Ficopomatus enigmaticus (Fauvel 1923), Crassostrea gigas (Thunberg 1793) and Undaria pinnatifida (Harvey) (Suringar 1872) (Orensanz et al. 2002). All five are euryocious species that originated in the Indo-Pacific Ocean; L. fortunei and $F$. enigmaticus colonized estuaries, the other invaded marine habitats. Though P. macrodactylus arrived in an oceanic port, it may also cope with wide variations in salinity and temperature and it is considered an estuarine species (Newman 1963; Born 1968).

Like another invasive crustacea with planktonic larvae, B. glandula that arrived to Mar del Pata Harbor in the early 1970's and spread immediately north and south, P. macrodactylus larvae may be dispersed in both directions, and may colonize brackish water habitats. Secondary introductions have been proposed for explaining the dispersal of P. macrodactylus from the Guadaquivir estuary to several other estuarine habitats in the Gulf of Cádiz, Spain (Cuesta et al. 2004).

Considering Mar del Plata as a possible center of dispersion, the nearest estuarine habitats are Mar Chiquita Lagoon (ca. $35 \mathrm{Km}$ North) and the estuary of Rio Quequén (ca. $120 \mathrm{Km}$ South). We propose that $P$. macrodactylus could spread to both habitats and, eventually, establish there. It will be interesting to follow this process, especially the possible interactions of $P$. macrodactylus with Palaemonetes argentinus (Nobili 1901), a freshwater, but rather euryhaline, native prawn that is found, at least, in Mar Chiquita Lagoon (Spivak, 1997). Only few specimens have been studied for parasites with negative results so far. We propose screening the prawns for viral infections and parasites.

\section{Acknowledgements}

The authors would thank Gregorio Bigatti and Paola Silva for kindly giving the specimens that they have found, José Antonio Cuesta for his review and advice, and Cédric d'Udekem d'Acoz for sending us the submitted manuscript "Occurrence of the Asian shrimp, Palaemon macrodactylus Rathbun, 1902, in the Southern Bight of the North Sea, with a key to the Palaemonidae of North-West Europe (Crustacea, Decapoda, Caridea)".

\section{References}

Anonymous (1997) An Evaluation of Potential Shrimp Virus Impacts on Cultured Shrimp and Wild Shrimp Populations in the Gulf of Mexico and Southeastern U.S. Atlantic Coastal Waters. A report to the Joint Subcommittee on Aquaculture prepared by the JSA Shrimp Virus Work Group, National Marine Fisheries Service, U.S. Department of Commerce, pp. 77.

Ashelby CW, Worsfold TM and Fransen CHJM (2004) First records of the oriental prawn Palaemon macrodactylus (Decapoda: Caridea), an alien species in European waters, with a revised key to British Palaemonidae. Journal of the Marine Biological Association of the United Kingdom 84: 1041-1050 
Born JW (1968) Osmoregulatory capacities of two caridean shrimps: Syncaris pacifica (Atyidae) and Palaemon macrodactylus (Palaemonidae). Biological Bulletin 134: 235-244

Boschi EE (1964) Los crustáceos decápodos brachyura del litoral bonaerense (R. Argentina). Boletín del Instituto de Biología Marina Mar del Plata 6: 1-99

Boschi EE (2000) Species of decapod crustaceans and their distribution in the american marine zoogeographic provinces. Revista de Investigación y Desarrollo Pesquero, Argentina 13: 7-136

Boschi EE, Fischbach CE and Iorio MI (1992) Catálogo ilustrado de los crustáceos estomatópodos y decápodos marinos de Argentina. Frente Marítimo, Argentina-Uruguay 10A: 7-94

Buckworth R (1979) Aspects of the population dynamics of Palaemon macrodactylus (Decapoda: Palaemonidae) in Lake Mannering, NSW, and in the laboratory. MSc., Thesis, University of New South Wales, Sydney, Australia

Chin P, Kim HY and Sin YK (1992) Energy budgets for the development stages of Palaemon macrodactylus. Bulletin of the Korean Fisheries Society 25: 341-358

Corbel V, Shi Z, Huang C, Arcier JM and Bonami JR (2001) Experimental infection of European crustaceans with white spot syndrome virus (WSSV). Journal of Fish Diseases 24: 377-382

Cuesta JA, González-Ortegón E, Drake P and Rodríguez A (2004) First Record of Palaemon macrodactylus Rathbun, 1902 (Decapoda, Caridea, Palaemonidae) from European Waters. Crustaceana 77: 377-380

Elías R and Vallarino EA (2001) The introduced barnacle Balanus glandula (Darwin) in the Mar del Plata port as a structuring species in the intertidal community. Investigaciones Marinas, Valparaíso 29(1), 37-46

Excoffon A, Genzano G and Zamponi M (1999) Macrobentos asociado con una población de Anthothoe chilensis (Lesson, 1830) (Cnidaria, Actiniaria) en el puerto de Mar del Plata, Argentina. Ciencias Marinas 25(2), 193-212

Fisher WS (1983a) Eggs of Palaemon macrodactylus. II. Association with aquatic bacteria. Biological Bulletin 164: 201-213

Fisher WS (1983b) Eggs of Palaemon macrodactylus. III. Infection by the fungus Lagenidium callinectes. Biological Bulletin 164: 214-226
Fisher WS and Clark WH (1983) Eggs of Palaemon macrodactylus. I. Attachment to the pleopods and formation of the outer investment coat. Biological Bulletin 164: 189-200

Furlani DM (1996) A guide to the introduced marine species in Australian waters. CRIMP Technical Report 5

Gestal C, Guerra A, Pascual S and Azevedo C (2002) On the life cycle of Aggregata eberthi and observations on Aggregata octopiana (Apicomplexa, Aggregatidae) from Galicia (NE Atlantic). European Journal of Protistology 37: 427-435

Jensen GC (1995) Pacific Coast: Crabs and Shrimps. Sea Challengers, Monterey, California, $85 \mathrm{pp}$

Little G (1969) The larval development of the shrimp, Palaemon macrodactylus Rathbun, reared in the laboratory, and the effect of eyestalk extirpation on development. Crustaceana 17: 69-87

Newman WA (1963) On the introduction of an edible oriental shrimp (Caridea, Palaemonidae) to San Francisco Bay. Crustaceana 5(2), 119-132

Orensanz JM, Schwindt E, Pastorino G, Bortolus A, Casas G, Darrigran G, Elías R, López Gappa JJ, Obenat S, Pascual M, Penchaszadeh P, Piriz ML, Scarabino F, Spivak E and Vallarino E (2002) No longer a pristine confine of the world ocean - A survey of exotic marine species in the Southwestern Atlantic. Journal of Biological Invasions 4: 115-143

Pezzani S, Stupak ME and Pérez MC (1996) Macrofouling community at Mar del Plata harbor during a one-year period (1991-92). Corrosion Reviews 14(3-4), 73-86

Rathbun M (1902) Japanese stalk-eyed crustaceans. Proceedings of the United States National Museum 26: 23-55

Schejter L, Spivak ED and Luppi TA. (2002) Presence of Pyromaia tuberculata (Lockington, 1877) adults and larvae in the Argentine continental shelf (Crustacea: Decapoda: Majoidea). Proceedings of the Biological Society of Washington 115(3), 116-121

Spivak E (1997) Life history of a brackish-water population of Palaemonetes argentinus (Decapoda Caridea) in Argentina. Annales de Limnologie 33(3), 179-190

Williams GD, West J, Cordrey M, Ward K (1999) The physical, chemical, and biological monitoring of Los Peñasquitos Lagoon, 1998-99. Annual report prepared for the Los Peñasquitos Lagoon Foundation 